\title{
蛇行流路内における粘弾性流体の流動および伝熱特性*
}

\author{
巽 和也 ${ }^{* 1,{ }^{*} 2}$, 永坂 亘 ${ }^{* 1}$, 中島 理"1, Heong Chee Leong ${ }^{* 1}$, 中部 主敬 ${ }^{* 2,{ }^{* 3}}$
}

\section{Flow and Heat Transfer Characteristics of Viscoelastic Fluid Flow in a Serpentine Channel}

\author{
Kazuya TATSUMI ${ }^{* 1, * 2}$, Wataru NAGASAKA, Osamu NAKAJIMA, \\ Chee Leong HEONG and Kazuyoshi NAKABE \\ ${ }^{* 1}$ Department of Mechanical Engineering and Science, Kyoto University \\ Yoshida Honmachi, Sakyo-ku, Kyoto-shi, Kyoto, 606-8501 Japan \\ ${ }^{* 2}$ Advance Research Institute of Fluid Science, Kyoto University \\ Kyoto daigaku-Katsura, Nishikyo-ku, Kyoto-shi, Kyoto, 615-8530 Japan
}

The heat transfer and fluid flow characteristics of a viscoelastic fluid flow in a serpentine channel are described in this paper. The average heat transfer coefficient, pressure loss, and flow visualization were measured under the Reynolds number conditions of $R e=0.5 \sim 2.0$. Water solutions of polyacrylamide with sucrose and plain sucrose were employed as viscoelastic fluids and Newtonian fluids, respectively. An increase in the Nusselt number with increasing Reynolds number in the case of the viscoelastic fluid flow was observed in the serpentine channel, while in the case of the Newtonian fluid flow, the Nusselt number remained approximately constant. The visualization results revealed that unsteady flows with a large fluctuation and longitudinal vortex-like secondary flows were generated in the case of the viscoelastic fluid flow, particularly downstream of the inflection point of the serpentine channel. This was believed to be attributed to the increase in the flow instability and the normal stresses produced by the elastic property of the fluids. Further, the Nusselt number increased even in the case of the viscoelastic fluid flow in the straight channel, relative to that in the case of the Newtonian fluid flow. However, this increase moderate in comparison to that in case of the serpentine channel, which indicates that the heat transfer enhancement can be obtained effectively by a combination of the viscoelastic fluid flow and channel geometry. A considerable increase in the pressure loss penalty was observed in the case of the viscoelastic fluid flow. However, the viscoelastic fluid case showed a higher overall performance in terms of the pumping power.

Key Words : Viscoelastic Fluid, Serpentine Channel, Flow Visualization, Low Reynolds Number Flow, Heat Transfer, Pressure Loss

1. 緒言

これまで低レイノルズ数流れにおける伝熱・混合性能の促進について数多くの研究が行われ，特に拡大伝熱面 としてのフィンや，はく離・再付着渦を形成する流路など，流路形状の改良による促進効果が図られてきた . 方，作動流体の特性を変化させて，伝熱・混合促進を行う方法も報告されている.例えば， Nano-Fluids と称され るものは, 流体中にナノ粒子を懸濁することで, 見かけの熱伝導率と壁面熱伝達率を向上させることができると されている(1)(2) .また，作動流体に微量の高分子を添加した粘弾性流体を活用する方法も発表されている. 粘弾性 流体では, 流れのせん断応力による高分子の伸縮・変形運動により付加的な粘性と共に弾性特性が生じるが, 光 の弾性による応力により二次流れと流れの不安定性が促進される場合があると考えられている .これにより，微 小流路内における低レイノルズ数流れでも流れが非定常化して乱れを生成し，混合・物質伝達・熱伝達を促進す

\footnotetext{
* 原稿受付 2012 年 7 月 27 日

*1 正員, 京都大学工学研究科（干606-8501 京都府京都市左京区吉田本町）

*2 京都大学工学研究科高等研究院流体理工学研究部門

( T615-8530 京都府京都市西京区京都大学桂)

*3 正員, フェロー, 京都大学工学研究科

E-mail: tatsumi@me.kyoto-u.ac.jp 
(a) Side view of the channel

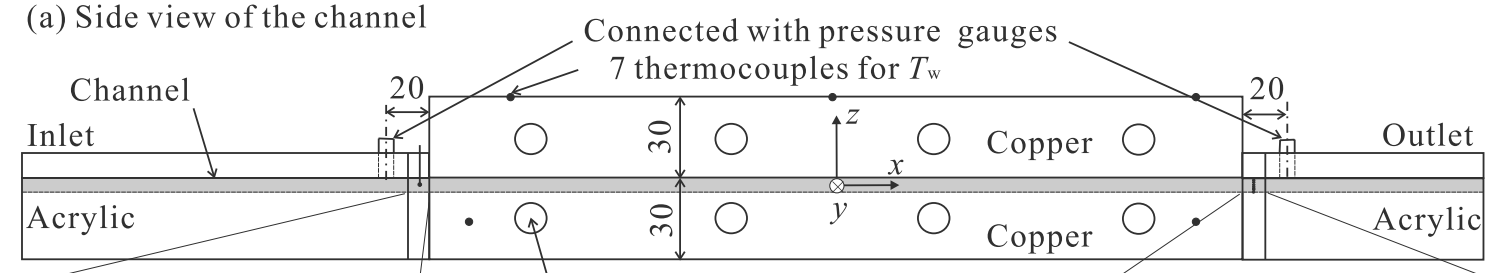

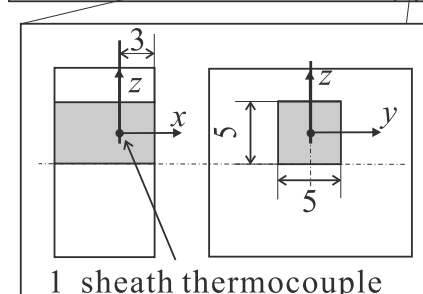

1 sheath thermocouple (b-1) Side and front views of the inlet temperature measurement area

for constant temperature water

(b-2) Top and front views of the curve

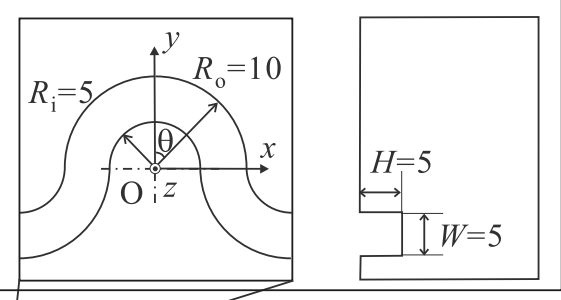

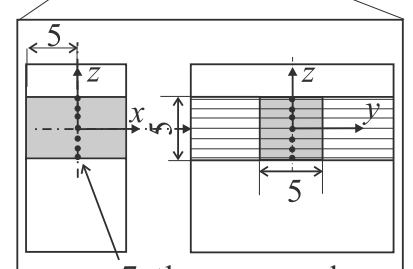

7 thermocouples (b-3) Side and front views of the outlet temperature measurement area

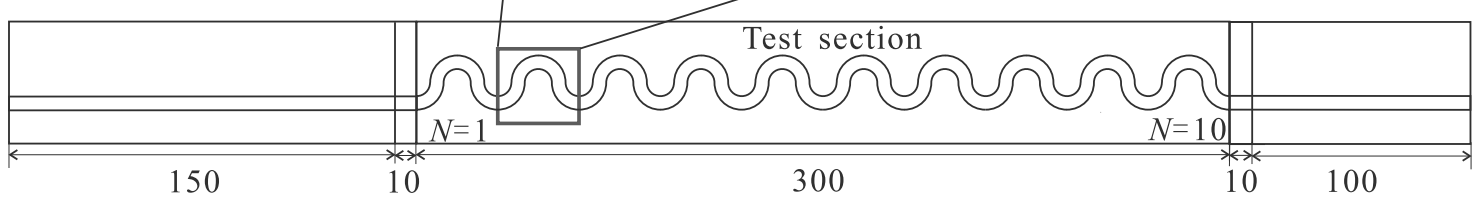

(c) Top view of the channel

Fig. 1 Schematic diagram of the experimental apparatus and the serpentine channel used in the heat transfer measurements.

\section{ることが新たな技術として以下のように試みられている．}

粘弾性流体流れの不安定性に関する研究では, Shaqfeh らが摂動解析や実験により同軸回転二重円筒内の TaylorCouette 流れ ${ }^{(3)}$, Taylor-Dean 流れ ${ }^{(4)}$ を対象に詳細な研究を行っている . また , 横山・富田は ${ }^{(5)}$ ，曲がり管内助走区 間における高分子添加溶液の流動について固体トレーサ法を用いた速度計測を行い，層流と乱流の両領域で乱れ の生成が促進されることを示した . 近年では, Groisman ら ${ }^{(6)}$ は，矩形断面蛇行流路内での流れの可視化とレーザ ドップラー流速計 (LDV) を用いた速度計測を行い，粘弾性流体による乱れと混合促進が得られると報告してい る.さらに,玉野ら ${ }^{(7)}$ は, 円形断面蛇行流路の下流領域での流れの可視化と粒子画像流速計 (PIV) による速度場 計測を行い, 時間平均速度分布において 2 次流れが形成されることを報告している．これに加えて，マイクロス ケールの蛇行流路内流れについても, 可視化実験の結果から流路内において流れの変動と混合促進効果が得られ ることが報告されている(8)(9)

このように, 蛇行流路内における粘弾性流体に関する流動および混合特性に関する研究が行われているが，伝 熱特性に関連づけた実験的知見はほとんど見当たらず，伝熱促進技術の開発を指向した計測を行う必要がある . 粘 弾性流体を用いた低レイノルズ数流れにおける伝熱促進効果としては, 直線流路内において二次流れ ${ }^{(10)}$ が生成さ れることにより熱伝達率か増加することか報告されている(11) (13). また , Norouzi らは ${ }^{(14)}$, 矩形曲がり管における 伝熱特性に関する数值解析を行い, 第一法線応力差の増大に伴い Tayor 渦が生成され, 平均又ッセル卜数か増加す ることを示した . 乥こで, 前述の蛇行流路ではこれら直線流路や曲がり管と比較してさらに流れの変動と強い二 次流れが形成されると考えられることから, 本研究では, ミリメートル寸法の蛇行流路内の低レイノルズ数粘弾 性流体流れにおける伝熱特性を解明することを目的とした．実験では，作動流体として，スクロース水溶液にポ リアクリルアミドを添加した粘弾性流体である溶液を用い，等温加熱条件下での平均熱伝達率測定と圧力損失測 定，ならびに流れの可視化を行うことで光の基本特性を示すと共に，ニュートン流体としてスクロースのみを添 加した水溶液の結果と比較することで, 伝熱促進効果の評価を行った . 


\section{2. 実験手法と条件}

\section{$2 \cdot 1$ 伝熱実験}

図 1 に実験で用いた流路の概観図と各部の寸法を示す.伝熱実験で用いる流路は，銅製の蛇行流路部と炎の入 口と出口に接続したアクリル製の直線流路部から構成される .

流路形状および寸法として，図に示すように，測定部である蛇行流路は半円形状の湾曲部が周期的に彫り込ま れた厚さ $30 \mathrm{~mm}$ の銅製ブロックから成る . 流路の断面は 1 辺 $5 \mathrm{~mm}$ の正方形である . 湾曲部の内半径 $R_{i}$ と外半径

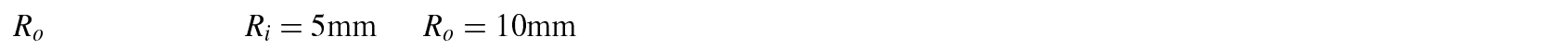
さ $30 \mathrm{~mm}$ の銅ブロックを設置した . また , 比較実験で用いた直線流路も銅製で, 兴の断面が 1 辺 $5 \mathrm{~mm}$ の正方形で あり，主流方向長さが蛇行流路の流路長 (断面中心線の長さ) に等しい $471 \mathrm{~mm}$ である.

蛇行, 直線いずれの流路についても, 弚の流路上流には作動流体で満たされた加圧容器か設置され, 容器内を昇 圧することで流体を流路へ供給する . 流体の質量流量は，実験中に流路出口から排出される流体の質量を電子天秤 (A\&D：GF-3000) を用いて測定し，時間で除した平均值として求めた。実験中の流量の変動はおよ光 $0.4 \mathrm{~mL} / \mathrm{min}$

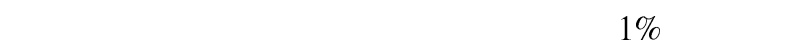

銅製の流路上下壁部には貫通孔が複数設けられ, 光こに恒温槽とポンプを用いて温度一定の水を循環させる .こ れにより，流路壁の温度を一定に保ち，等温加熱条件を適用した . また，流路内の気泡の発生の抑制と高分子の 変性を防ぐため, 壁面の最高温度は $40^{\circ} \mathrm{C}$ を越えないように設定して実験を行った . 流体温度は, 図 1 に示すよう に，流路入口では $0.5 \mathrm{~mm}$ 径の $\mathrm{K}$ 型シース熱電対を流路内に挿入し，流路断面中心の流体温度を測定した . 流路出 口では, $0.1 \mathrm{~mm}$ 径の $\mathrm{K}$ 型裸熱電対を流路幅方向に張り渡し，乥の中心温度を高さ方向に等間隔で 7 箇所測定した。 この場合，流路断面内において高さ方向にも幅方向にも温度分布が相似であることを仮定して，測定した $y$ 方向 の温度分布から $y-z$ 断面内の 2 次元温度分布を算定した . これに正方断面流路内の層流流れの速度分布を適用す ることで流体のバルク平均温度を見積もった . 速度分布については , 作動流体として 2.3 節で述べるスクロース水 溶液の場合には，ニュートン流体に関する矩形流路内速度分布 ${ }^{(15)}$ を用いた .

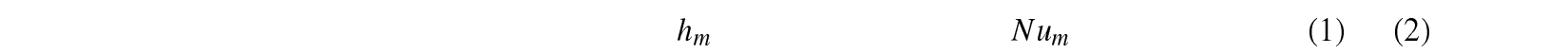
求めた.

$$
\begin{gathered}
h_{m}=\frac{\dot{m} c_{p}}{A_{s}} \times \ln \frac{T_{w}-T_{b, i}}{T_{w}-T_{b, o}} \\
N u_{m}=\frac{h_{m} D_{h}}{k}
\end{gathered}
$$

$\dot{m}$ と $c_{p}$ は流体の質量流量と等圧比熱容量であり， $A_{s}$ は伝熱面積である.$T_{w}$ は壁面温度であり， $T_{b, i}$ と $T_{b, o}$ は光れ 流路入口と出口での流体バルク平均温度である．また， $D_{h}$ と $k$ は光れ午れ流路の水力直径と流体の熱伝導率 である .

一方, 粘弾性流体であるポリアクリルアミド水溶液では, Wiginton と Dalton ら $^{(16)}$ が示す円管内のべき乗則流体 流れの速度分布を適用した . この場合, ニュートン流体における円管と矩形流路の速度分布の関係に基づいてべ き乗則流体流れの矩形流路内速度分布に変換した次式を用いた．

$$
\begin{array}{r}
\frac{u}{u_{m}}=\left[0.14\left(\frac{r}{a}\right)^{4}-0.334\left(\frac{r}{a}\right)^{3}+0.28\left(\frac{r}{a}\right)^{2}+0.0161\left(\frac{r}{a}\right)+1.06\right] \\
\times \frac{3 n+1}{n+1}\left[1-\left(\frac{y}{2.5}{ }^{(1.2 n+1) / n}\right)\right]\left[1-\left(\frac{z}{2.5}\right)^{(1.2 n+1) / n}\right]
\end{array}
$$

ここで, $r / a=y / 2.5=z / 2.5$ であり, $n=1 / 3$ である .

流路壁面温度は流路の壁面を構成する銅ブロックに熱電対を 7 箇所埋込んで温度を測定し，弚の平均值を壁面

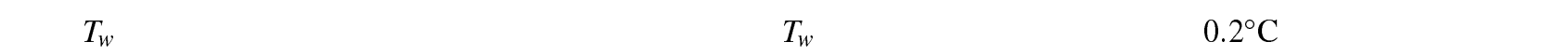
の場合，銅の熱伝導率と直線流路内の層流熱伝達率を用いて求めたビオ一数 $B i$ は $B i<0.1$ であることから，等温 加熱条件を妥当であるとした .

また本実験では，圧力損失の測定も熱伝達率測定と同時に行った .この場合，流路入口と出口における流路上壁 に設けた $1 \mathrm{~mm}$ 径の穴にチューブを介して圧力計を接続することで差圧を測定した . 圧力計は, 流路内の流量 (差 
圧) に応じて微差圧計 (SMC 製：PSE550) と圧力計 (キーエンス：AP-C30) を使い分けた . これらの熱電対およ び圧力計からの出力信号は全て , A/D 信号変換器（横河電機 : WE7231 W7000）を介してパソコンに収録した .

\section{$2 \cdot 2$ 可視化実験}

流動特性を定性的に観察するために，染料（メチレンブルー）を用いた可視化実験を行った．実験では，図 1 に 示す銅製の蛇行流路部を透明アクリル製の流路と取り替えて測定を行った．したがって，可視化害験は非加熱の等 温 (室温) 条件下で行った . 蛇行流路の上流にある直線流路上壁中央に設けた穴には, 外径 $1.06 \mathrm{~mm}$, 内径 $0.56 \mathrm{~mm}$ のPTFE チューブを挿入した .このチューブには流路断面中央の位置に微小孔が流れに対向して設けられており， シリンジポンプ (日本光電: CFV-3200) を用いて 200〜 750 $\mu \mathrm{L} / \mathrm{min}$ の流量で染料をチューブに供給することで, 微 小孔から染料か流路内に供給される .この時，染料の粘性を作動流体の光れと等しくするために，64.4 wt\% のスク ロース水溶液に染料を混入したものを用いた . 動画の撮影には 2 台のデジタルビデオカメラ (Sony : HDR-CX370V, 30fps）を用い, 流路上方および側方の 2 方向から可視化撮影を行った .これら両方向からの撮影は同期させて行っ た。

\section{$2 \cdot 3$ 作動流体と実験条件}

実験で用いる粘弾性流体は，64.4wt\% スクロース水溶液に $1 \mathrm{wt} \% \mathrm{NaCl}$ と $500 \mathrm{ppm}$ のポリアクリルアミド (Polyscience : 分子量 $\mathrm{MW}=1.8 \times 10^{7}$ ) を添加した溶液である (以降 PAAm 水溶液と称す) . 本実験では，スク ロース水溶液を溶媒として用いることで後述する緩和時間 $\lambda$ の増大を図った . また，PAAm の凝集を抑制するた めに $\mathrm{NaCl}$ をカウンターイオンとして混入している . 実験では , 粘弾性流体との比較を行うためのニュートン流体 として $64.4 \mathrm{wt} \%$ のスクロース水溶液を用い，測定時のレイノルズ数範囲を合わせた .

溶液の作成手順を以下に示す.スクロース水溶液については, 水道水に $64.4 \mathrm{wt} \%$ のスクロースを混ぜた溶液を 円筒容器に封入し，室温にて容器を回転ミルを用いて $120 \mathrm{rpm} て ゙ 12$ 時間回転することで作製した . 一方，PAAm

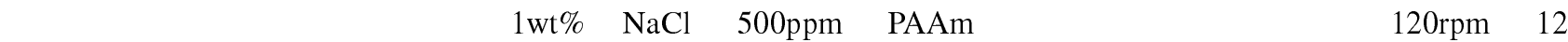
時間容器を回転させて PAAm を充分に混合する . 弚の後 , 64.4wt\%のスクロースを追加して , さらに 12 時間回転 させて作製した .

各溶液に関する物性値の求め方を以下に示す . 流体の密度 $\rho$ については，電子天秤を用いて求めた．また，式 (1) と (2) で用いる定圧比熱容量 $c_{p}$ と熱伝導率 $k$ については, 弚れ光れ文献 ${ }^{(17)(18)}$ で示されたスクロース水溶液に 関する温度と濃度に対する両物性値の関係式を利用した . 実験における流体の温度変化 $15 \sim 40^{\circ} \mathrm{C}$ に対するこれ らの物性值の変化は， $\rho$ では約 $1 \%, c_{p}$ と $k$ では共に約 5\%である.実験で用いた流体の代表温度は，流路入口部， 出口部におけるバルク平均温度から求まる対数平均温度を用いた．また，PAAm 水溶液では, PAAm の濃度がス クロースの濃度と比較して小さいことから,$c_{p}$ と $k$ についてはスクロース水溶液の場合と同じ関係式を用いた

粘性係数 $\mu$ と緩和時間 $\lambda$ は，溶液の濃度と温度の影響を顕著に受ける．光のため，レオメータ (Anton Paar : MCR301) を用いて実験ごとに温度およびひずみ速度との関係を測定した . はじめに，スクロース水溶液の $\mu$ の 測定では，一定せん断速度 $\left(\dot{\gamma}=50 s^{-1}\right)$ で約 $1^{\circ} \mathrm{C}$ の間隔で $\mu$ を測定し，文献 ${ }^{(19)}$ に記載の式 (4) に基づいて相関式 を求めた . なお式中の $T_{\mathrm{m}}\left[{ }^{\circ} \mathrm{C}\right]$ は流体温度である . 測定の結果 ，各係数は $\alpha_{\mu}=0.58, \beta=-3.1 \times 10^{3}, \varepsilon=8.0 \times 10^{5}$ であった .ここでスクロース水溶液の場合における各測定の $\alpha_{\mu}, \beta, \varepsilon$ につて精密度を基にして誤差を求めた場

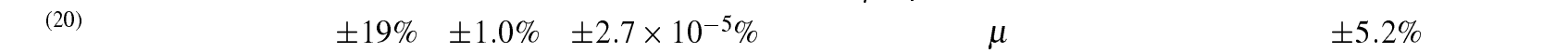

$$
\log _{10} \mu\left(T_{\mathrm{m}}\right)=\alpha_{\mu}+\frac{\beta}{\left(T_{\mathrm{m}}+273\right)}+\frac{\varepsilon}{\left(T_{\mathrm{m}}+273\right)^{2}}
$$

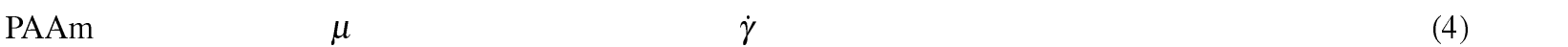
た関係では， $\beta$ と $\varepsilon$ は変化せず, $\beta=-3.6 \times 10^{3}, \varepsilon=7.9 \times 10^{5}$ でほぼ一定であった（ $\beta$ と $\varepsilon$ に関する誤差は光れ 光れ $\dot{\gamma}=5.0 s^{-1}$ の場合で $\pm 2.7 \%$ と $\pm 8.0 \times 10^{-5} \%$ であり， $\dot{\gamma}=50 s^{-1}$ では $\pm 1.9 \%$ と $\pm 5.5 \times 10^{-5} \%$ であった）. 光 こで, 実験ごとの $\mu$ を以下の手順で求めた . はじめに, PAAm 水溶液はべき乗則流体であるとして , 実験ごとに 作動流体の $20^{\circ} \mathrm{C}$ における関係式 
Table 1 Experimental conditions of the heat transfer measurements.

\begin{tabular}{c|c|c|c|c}
\hline \hline fluid & $U_{\mathrm{m}}[\mathrm{mm} / \mathrm{s}]$ & $R e$ & $N_{D}$ & $W i$ \\
\hline Sucrose & $10-40$ & $0.82-2.40$ & $0.40-1.60$ & - \\
\hline PAAm (with sucrose) & $10-81$ & $0.23-2.64$ & $0.04-0.49$ & $11.7-140$ \\
\hline
\end{tabular}

$$
\mu=K \dot{\gamma}^{n-1}
$$

を $\dot{\gamma}=1 \sim 100 s^{-1}$ の範囲で予め求める. PAAm 水溶液の $20^{\circ} \mathrm{C}$ における值の一例として $, K=0.55, n=0.88$ で あった . 次に，実験における流路内の代表せん断速度を $\dot{\gamma}=4 U_{m} / D_{h}$ として定め，弚のせん断速度における $\mu$ を 式 (5) から求める.ここで, $U_{m}$ は流路内流れの断面平均流速である. 光の結果, 式 (4) における $\alpha_{\mu}$ が求まる.最 後に，実験の代表温度を求め，これを式 (4)に代入することで炎の温度における $\mu$ を求めた .

PAAm 水溶液の緩和時間 $\lambda$ につては, 本実験で用いる溶液の濃度が小さくレオメータによる直接測定か灘し いため, 一定ひずみ付加後の応力分布に対して，応力緩和に関する Maxwell の一般化モデルを適用して求めた . は じめに，流体温度による $\lambda$ への影響を求めるため，15,20,30,40 C における $\lambda$ を光れ光れ測定した . PAAm 水溶 液における $\mu$ と温度との関係における $\beta$ と $\varepsilon$ をにも光のまま適用できると仮定すれば，この結果に式 (4) を適 用して $\lambda$ と温度の関係も求めることが可能となる.実際， $\beta$ と $\varepsilon$ における誤差は光れ光れ $\pm 9 \%$ と $\pm 2.4 \times 10^{-4} \%$ であった . 弚こで, 実験ごとに予め $20^{\circ} \mathrm{C}$ における $\lambda$ を測定し，光の值から式 (4) と同形式の $\lambda$ に関する式におけ る $\alpha_{\lambda}$ を求める . 弚の式に，実験の代表温度を適用し，実験における $\lambda$ を定めた .

測定の一例として PAAm 水溶液の粘性係数 $\mu$ は $20^{\circ} \mathrm{C}, \dot{\gamma}=200 \mathrm{~s}^{-1}$ において $\mu=0.31 \mathrm{~Pa} \cdot \mathrm{s}$ であり，緩和時間 $\lambda$ は

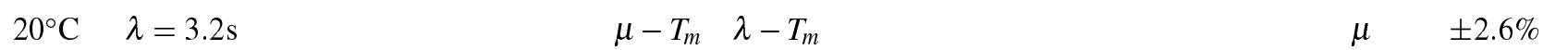
$\lambda$ では $\pm 7.5 \%$ であった . また, PAAm 水溶液の物性值に関する経時変化が存在する場合があるため ${ }^{(21)}$, レオメー タにより溶液作成後 72 時間以内では物性値変化がないことを確認した上で, 全て产の時間内で実験を行った .

伝熱実験の条件を表 1 に示す.実験では流量を変化させて，レイノルズ数 $R e\left(R e=\rho U_{m} D_{h} / \mu\right)$ の範囲が $0.82 \leq R e \leq 2.40$ となる条件で，熱伝達率および圧力損失の測定を行った . 表中の $N_{D}$ と $W i$ は，乥れぞれディーン 数とワイゼンベルグ数であり, 式(6)のように定義され，いずれも Re 数と共に増加する.可視化実験については,

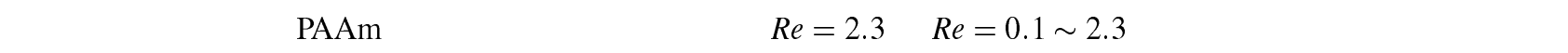

$$
N_{D}=\operatorname{Re} \sqrt{\frac{D_{h}}{\left(R_{i}+R_{o}\right)}}, \quad W i=\frac{4 \lambda U_{m}}{D_{h}}=\operatorname{Re}\left\{\frac{4(\mu / \rho)}{D_{h}^{2} / \lambda}\right\}
$$

\section{3. 結果と 考 察}

\section{$3 \cdot 1$ 可視化実験の結果と考察}

図 2 は, PAAm 水溶液を用いた場合の, 上流から 2 周期目 $(N=2)$ の湾曲部における可視化実験の結果である 図の上下に示す画像は光れ光れ流路の側面と上面から同期させて撮影したものであり，これらは同時刻の画像対

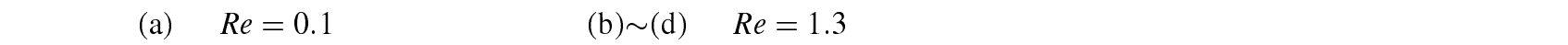
れ示す．

图 2(a)では, 流脈線が蛇行流路に沿って流路の高さと幅方向にほとんど変動せず，拡散もしないことが見てと れる.ここでは示さないが, スクロース水溶液の場合では, 検討した $R e$ 条件 $(R e=2.3)$ において同樣の特性を

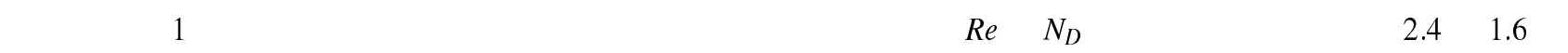
小さい．このため，流れは定常であり，また湾曲部においても顕著なディーン渦は形成されない．PAAm 水溶液 においても，図 2(a) に示すようにReが小さい条件では，流れは定常で二次流れも形成されないことが分かる．

$\mathrm{PAAm}$ 水溶液の $R e$ か増加すると流れは非定常となり，(b) (d) に示す $R e=1.3$ の条件では，流路スパン方向に 流脈線が大きく変動する．この条件では蛇行流路上流に位置する直線流路でも流脈線のスパン方向への移動が見 られた .これは粘弾性流体の第一, 第二法線応力差によって生じる二次流れの影響であると考えられるが, 湾曲 


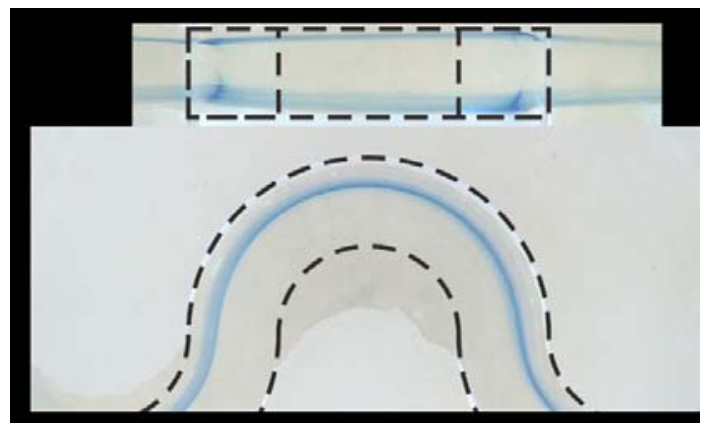

(a) $R e=0.1, W i=21.2, N_{D}=0.1$

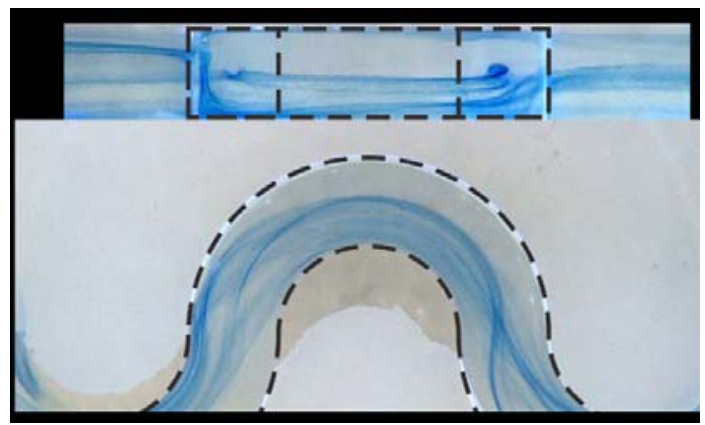

(c) $R e=1.3, W i=184, N_{D}=1.1($ period 2$)$

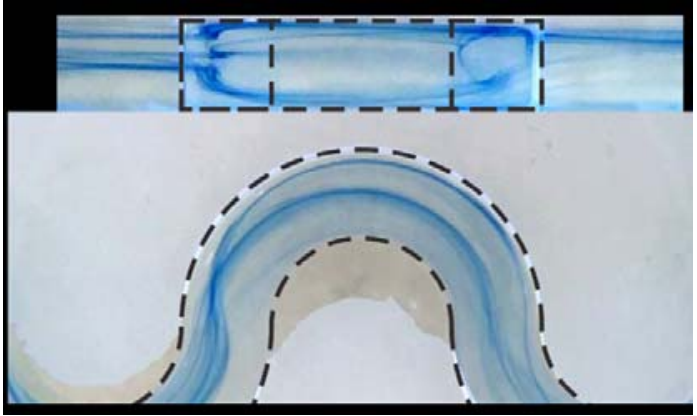

(b) $R e=1.3, W i=184, N_{D}=1.1($ period 1$)$

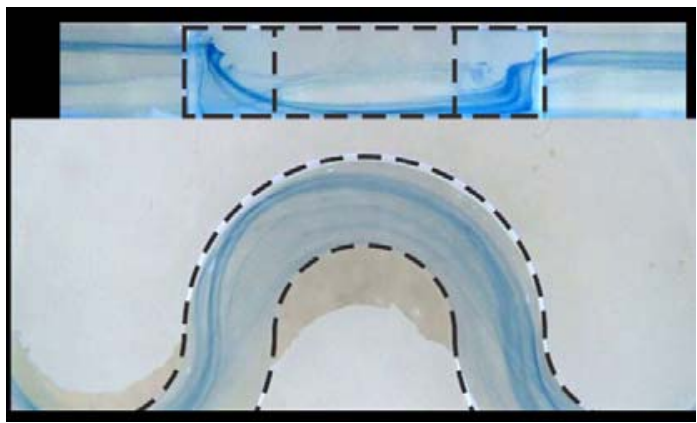

(d) $R e=1.3, W i=184, N_{D}=1.1($ period 3$)$

Fig. 2 Visualization for the streak lines (upper and lower images shown in each figure are the side view and overhead view of the channel respectively).

部における変動と比較すると弚の大きさは小さかった．したがって，蛇行流路内流れに対する上流の直線流路部 における変動の影響は小さいと考えられる．

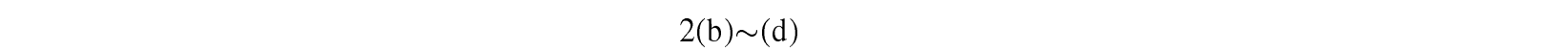
行う . はじめに, (b) では半円の湾曲部が接続する蛇行流路の変曲点である $\theta=-90^{\circ}$ のすぐ下流において , 側方 から見た場合，流路中央から上壁側と下壁側へ光れ艺れ向かう 2 種類の流脈線が見られる .これらを流路上方から 撮影した画像と比較した場合，前者は半径方向内向きに移動するもの，後者は逆に外向きに移動するものに対応 した．したがって，この時刻では， $\theta=-90^{\circ}$ 近傍の領域で分岐する一対の双子渦状の二次流れが形成されている

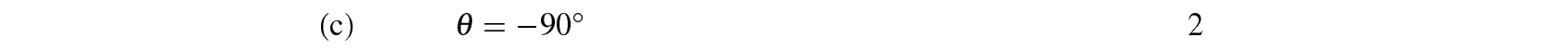
下流では, 前者は高さ方向と半径方向に位置を変えず, 後者は湾曲外縁に沿って下壁側へ向かうと共に, 半径方向 内側入流れる . また, (d) でも同樣に $\theta=-90^{\circ}$ の下流では, 流脈線は流路外縁の上壁近傍から側壁に沿って下壁 側へと流れることが分かる.これらのことから，(c) と (d) の時刻では, 流路中央を中心とした反時計まわりの単 一の縦渦状の二次流れが形成されていると考えられる .

図 2(b) (d) の全てにおいて，このように流脈線が大きく変化する領域は $\theta \simeq \pm 90^{\circ}$ の変曲点近くに位置する . こ れに対して, 湾曲部や炎の頂点である $\theta=0^{\circ}$ では, 流路高さ方向と半径方向への流脈線の位置の変化は小さい， これは他の時刻においても同樣に見られる傾向であり, 上述の二次流れは主に変曲点近くにて存在し, 湾曲部では 減衰して错の影響も減少すると言える .さらに, 単一渦と双子渦のように, 渦の構造は時間と共に変化すること が分かる.他の湾曲部を含めた可視化動画で見られた流脈線の変動, すなわち蛇行流路内の非定常な流れは, 主 にこの二次流れの時間的変化に伴うものであると考えられる .このことから，流れの空間的および時間的変動は， 湾曲の頭頂部近傍よりも変曲点の方か顕著であり，次節で述べる伝熱促進効果はこの二次流れによるものである と言える .

\section{$3 \cdot 2$ 圧力損失測定の結果と考察}

Fanning の管摩擦係数 $f=\Delta P D_{h} / 2 \rho U_{m}^{2} L$ とレイノルズ数 Re の関係を図 3 示す . ここで, $\Delta P$ は流路内の圧力損 失である . 図には, 直線流路と蛇行流路におけるスクロース水溶液流れの結果と, 直線流路と蛇行流路における 
PAAm 水溶液流れの結果を示す．また，図に示す破線は，ニュートン流体における正方断面流路内の発達流れに 関する解析解 $f=14.2 / R e^{(15)}$ である . 同図からスクロース水溶液の場合での直線流路 ( $\times$ 印) と蛇行流路 (。印) の結果は同じような傾向を示していることが分かる . 前節の可視化実験の結果でも述べた通り，本実験条件では ディーン数 $N_{D}$ が小さいため, 蛇行流路内の湾曲部においても二次流れが弱く, 圧力損失や伝熱に与える影響は無 視し得る．兴のため，蛇行流路の場合の $f$ は，直線流路の值とほほ等しくなると考えられる，一方，両者を破線 の解析解と比較すると $f$ がやや小さいことが分かる .これは, 本実験で用いるスクロース水溶液はPAAm 水溶液 と同樣に流体温度の粘性係数 $\mu$ への影響が大きいためであると考えられる .すなわち，流路断面内での $\mu$ の顕著 な変化のために一樣温度の場合と異なる速度分布が得られ，弚れにより $f$ が減少したと考えられる . 弚こで, 円 管内流れに関する補正式ではあるが，流路内の温度分布の影響を考慮して，式(7)に示すような修正管摩擦係数 $f^{\prime}$ を用いる(22).

$$
f^{\prime}=\frac{14.2}{R e}\left[\frac{\mu\left(T_{\mathrm{w}}\right)}{\mu\left(T_{\mathrm{m}}\right)}\right]^{\zeta}
$$

$\mu\left(T_{\mathrm{w}}\right), \mu\left(T_{\mathrm{m}}\right)$ は，光れ攵れ壁面温度 $T_{\mathrm{w}}$ と流体バルク平均温度 $T_{\mathrm{m}}$ における粘性係数である.べき数 $\zeta$ は, 定 数として 0.58 を適用する ${ }^{(22)}$. 実験で得られた温度分布を基に計算した $f^{\prime}$ の直線を, 図 3 に実線として示す. 図に 示す通り，スクロース水溶液の分布は蛇行流路，直線流路を問わず $f^{\prime}$ と良好に一致することが分かる .これによ り，圧力損失測定法の妥当性が確認できる。

次に, PAAm 水溶液 (・印と＋印) の結果については, $R e<0.35$ の領域でスクロース水溶液の場合と近い值を 示す.一方, $R e>0.35$ の領域では, $R e$ の増加に伴い管摩擦係数は増加して, スクロース水溶液および $f, f^{\prime}$ の分 布から大きく離れる.これは蛇行流路の場合においては，可視化実験で述べたようにReが小さい場合では流れは 定常で二次流れも生成されないが, Re か増加すると流れが非定常となるだけでなく，主流方向断面内に二次渦が 形成され，弚れが成長するためと考えられる．

PAAm 水溶液はべき乗則流体に属し，せん断速度によって粘性係数が変化するため，速度分布および管摩擦係 数の值はニュートン流体の場合と異なる．この場合，べき乗則流体の直線流路における定常流れに関する管摩擦 係数は, 式 (8) で示される修正レイノルズ数 $R e^{*}$ を用いた $f=16 / R e^{*}$ を採用することにした ${ }^{(11)(23)}$.

$$
R e^{*}=\frac{\rho U_{\mathrm{m}}^{2-n} D_{\mathrm{h}}^{n}}{8^{n-1} K(B+A / n)^{n}}
$$

ここで $, K, n$ は 2.3 節で示したべき乗則における定数であり， $A, B$ は正方断面流路の值として光れ光れ 0.2121 ， 0.6766 を適用する . 図 3 に示す結果を $f$ と $R e^{*}$ の関係に直した分布を図 4 に示す . また,$f=16 / R e^{*}$ の関係を破 線で図中に示す.さらにPAAm 水溶液の場合もスクロース水溶液の場合と同樣に , 流路断面内における温度分布 の影響を考慮する必要があるため, 式(7) と同樣の補正を行った . 䒓の結果を実線として図に示す．

$R e^{*}<0.4(R e<0.35)$ の領域では，PAAm 水溶液を用いた場合の直線流路 (+印) と蛇行流路 (・印) の結果 は互いによく一致する. また产の分布は図 3 の場合に比して実線とより良い一致を示す．前述の可視化実験の通 りPAAm 水溶液流れが定常流であるこの領域では，R $e^{*}$ で良く整理できることが分かる.

一方， $R e^{*}>0.4$ の領域では, 図 3 の傾向と同樣に, 直線流路と蛇行流路の管摩擦係数は共に $R e^{*}$ の増加に対す る減少率が小さくなり，产の值は解析解よりも大きくなる . また,$f=16 / R e^{*}$ から外れる時の $R e^{*}$ の值は両流路で 同じであるが, さらにR $e^{*}$ か増加すると，蛇行流路の場合の方が $f$ は大きくなる . 直線流路の場合において,$R e^{*}$ か増加する場合に， $f=16 / R e^{*}$ の関係が満たされず, 文献 ${ }^{(11)(12)(23)}$ の結果と異なる結果となる理由として,Wiの 違いが挙げられる . 本実験では，スクロース水溶液にPAAm を混ぜることで低い $R e$ 領域でも $W i$ は高い值を示す このため, 程度に違いはあっても直線流路内流れにおいても, 蛇行流路内流れで観測されたような流れの非定常 性や大規模な縦渦の形成へと発展する二次流れか顕われ，兴れに伴って圧力損失の増大か湿著になったと考えら れる。

\section{$3 \cdot 3$ 熱伝達率測定の結果と考察}

本節では伝熱実験の結果について検討を行う．図 5 に平均ヌッセルト数 $N u_{m}$ とRe の関係を示す．また，図 6 に $N u_{m}$ と修正レイノルズ数 $R e^{*}$ の関係を示す. 


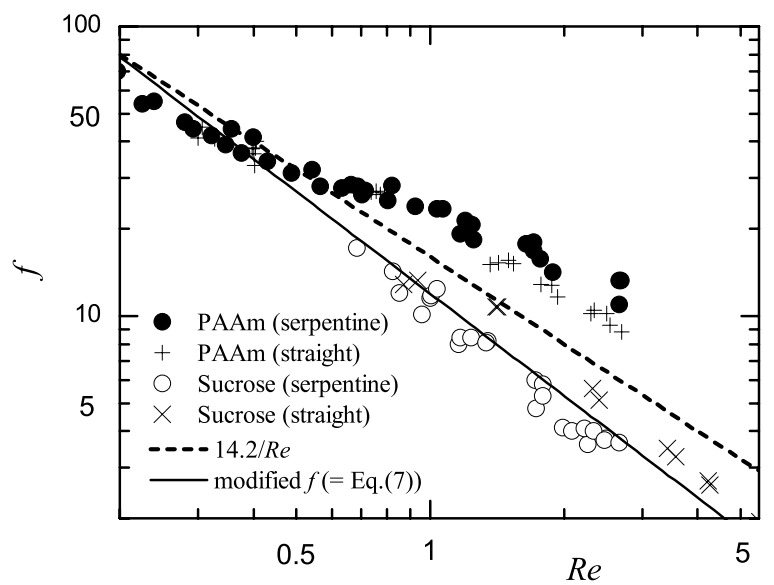

Fig. 3 Relationship between friction factor, $f$ and Fig. 4 Reynolds number, $R e$.

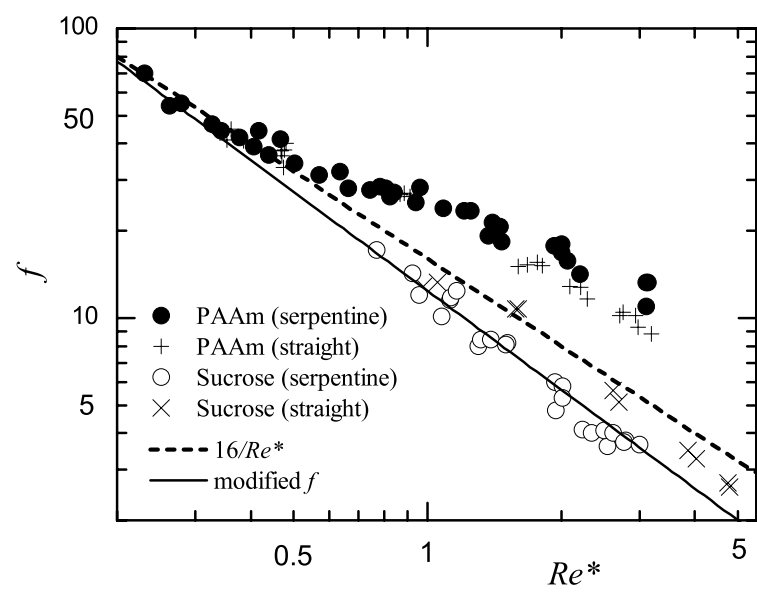

Relationship between friction factor, $f$ and modified Reynolds number, $R e^{*}$ on the basis of the power law fluid.

はじめに，図 5 においてスクロース水溶液を用いた場合における直線流路 ( $\times$ 印) と蛇行流路 ( $\square$ 印) につい て考察を行う . 図には比較のため, 等温加熱条件下における正方断面の直線流路内での, 助走区間の影響を考慮 したニュートン流体の解析結果 ${ }^{(24)}$ を破線で示す.さらに，この解析結果について，管摩擦係数 $f$ の場合と同樣に 流路断面内の温度分布による $N u_{m}$ に対する補正 ${ }^{(22)}$ を適用した結果を図中に実線で示す. 図において , スクロース 水溶液の場合では, 図 3 の場合と同樣に, 直線流路と蛇行流路の $N u_{m}$ 分布は互いにほとんど一致し, 蛇行流路内 にて顕著な二次流れが形成されていないことが分かる.また，これらの結果は補正した解析解と良好な一致を示 すことから，本実験の妥当性が確認できた．

次に, 図 5 と図 6 において PAAm 水溶液を用いた場合を見ると, $R e<0.4\left(R e^{*}<0.47\right)$ の領域では直線流路 $(+$ 印) および蛇行流路 (印) の両方の結果は, 解析結果に漸近していることが分かる.したがって, 図 3 および 4 でも述べた通り，この領域において流れは定常であり顕著な二次流れが存在しないと考えられる．弚の結果，粘 弾性流体を用いた伝熱促進効果が得られないことが分かる。

これに対して,$R e>0.4\left(R e^{*}>0.47\right)$ では, PAAm 水溶液の場合はスクロース水溶液の場合と比較して, Re の増 加と共に $N u_{m}$ が増加する . 特に , 蛇行流路内流れの場合では増加は顕著である . $R e=2.7\left(R e^{*}=3.1\right) て ゙ は ~ N u_{m}$ は 約 12 となり，同 $R e$ 条件におけるスクロース水溶液の場合と比較して約 3 倍の値を示すことから, 高い伝熱促進 効果が得られることが分かる.一方, PAAm 水溶液の直線流路の場合には, 兴の増加率は蛇行流路の場合と比較 して小さく,$R e=2.6$ では $N u_{m}=6.8$ とスクロース水溶液の場合に対して 1.5 倍程度である . 前節の末尾で議論し たように，本研究で用いた粘弾性流体流れでは，Re は小さいが $W i$ は比較的大きい.このため, 直線流路におい ても二次流れが $f$ や $N u_{m}$ の増大に寄与していると考えられる．しかし，式 (6)に示される粘弾性流体特有の諸物 性を変化させて熱流動現象に及ぼす影響を別途より詳細に調査し，第一，第二法線応力差による二次流れへの影 響について評価する必要がある. 本実験の蛇行流路では図 2 で示した可視化実験で見られたような, 流路断面全

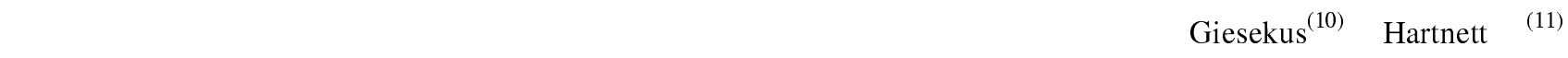
が示すような矩形直線流路における軸対称な渦形成は弱く，伝熱促進効果が低くなったと考えられる．

$R e$ に対する管摩擦係数 $f$ と平均ヌッセルト数 $N u_{m}$ の関係が示すように, 伝熱性能が増加すると共に, 圧力損 失も顕著に増加することが分かる．乥こで，蛇行流路内の粘弾性流体流れの伝熱に係る総合性能を評価するため に，図 7 にポンプ動力 $\Delta P U_{m}$ と $N u_{m}$ の関係を示す . スクロース水溶液と $P A A m$ 水溶液の場合共に $\triangle P U_{m}<100$ の 領域では, 定常流れとして流動特性が等しく, 前述の通り $f$ と $N u_{m}$ はいずれも同一の值を示したことから, 直線 流路 (+印) と蛇行流路（回印）の場合に依らず，ポンプ動力に対する $N u_{m}$ は同じ値を示し，スクロース溶液の 実線とも一致する .これに対して, $\Delta P U_{m}>100$ の領域では，流れが非定常となり二次流れが形成されることて蛇 行流路については, ポンプ動力に対する $N u_{m}$ の増加率は PAAm 水溶液の場合の方がより大きく，より高い性能を 示すことが分かる．これに対して, PAAm 水溶液で直線流路を用いた場合では，ポンプ動力に対する $N u_{m}$ の分布 はスクロース水溶液の場合とほぼ同じである．したがって，図3（あるいは4）と6で示したように，直線流路で 


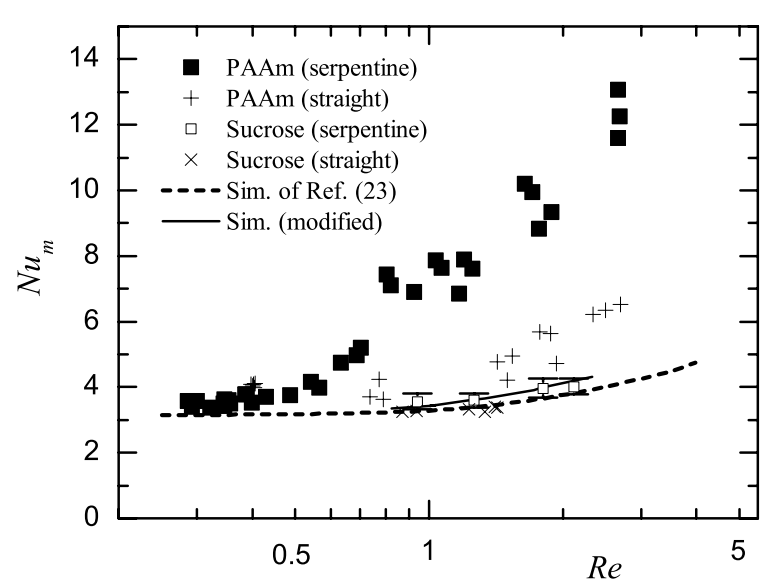

Fig. 5 Relationship between $N u_{m}$ and $R e$ in the cases Fig. 6 of sucrose and PAAm solutions.

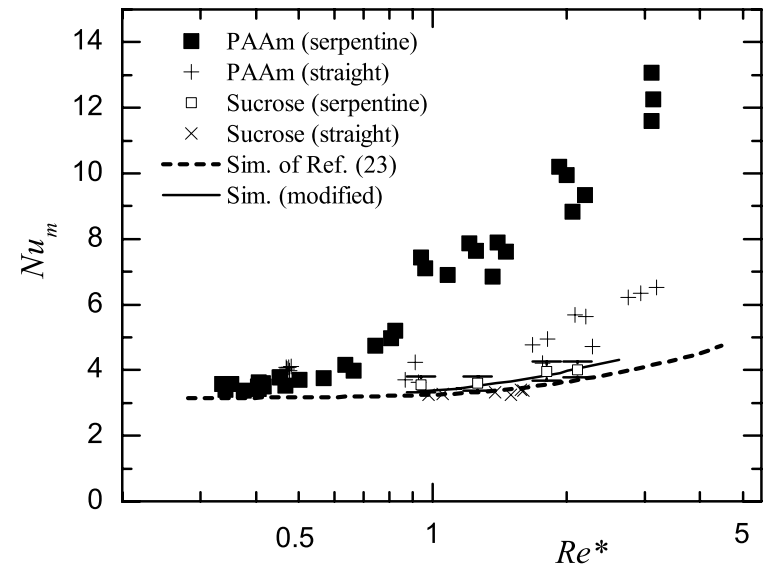

Relationship between $N u_{m}$ and $R e^{*}$ in the cases of sucrose and PAAm solutions.

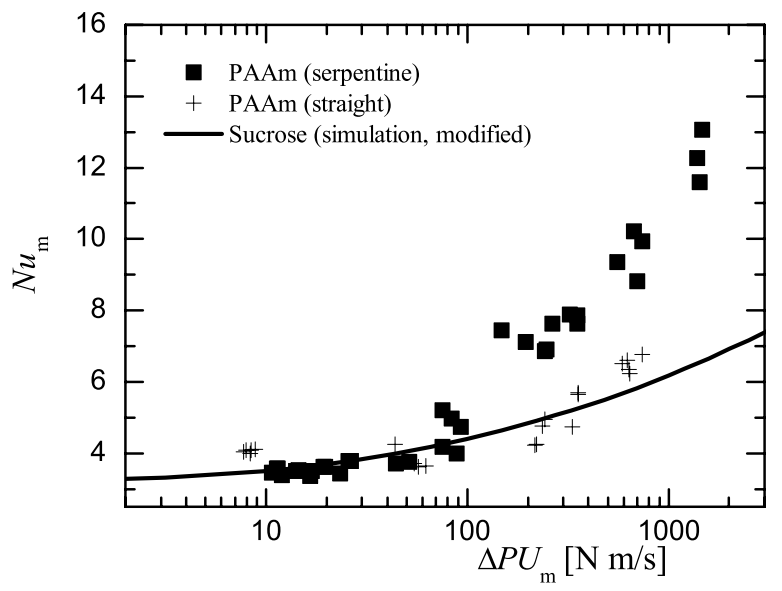

Fig. 7 Total performance evaluated by the relationship between the pumping power $\triangle P U_{m}$ and $N u_{m}$.

は粘弾性流体により二次流れが形成されて伝熱促進効果が得られるものの，同程度の圧力損失の増大が生じるた め総合性能としてはスクロース水溶液とほぼ等しくなることが分かった .

従って粘弾性流体を用いることで低レイノルズ数領域でも伝熱促進効果が得られるだけでなく, 蛇行流路内粘弾 性流体流れの場合では, 蛇行流路の変曲点近くで強い縦渦状の二次流れが形成されたため総合性能でも高い值を 示すことが分かった .

\section{4. 結言}

本研究では, 正方断面を持つ蛇行流路内の粘弾性流体流れにおける伝熱および流動特性の解明を目的として,ポ リアクリルアミドとスクロース混合水溶液 (PAAm 水溶液) を用いて, 可視化実験ならびに等温加熱条件下にお ける平均熱伝達率と圧力損失の測定を行った . 以下に , 得られた主な結果を示す．

1. 可視化実験では, PAAm 水溶液の場合において低レイノルズ数領域 $(R e<0.35)$ では, ニュートン流体である スクロース水溶液の場合と同樣に, 流れは定常て顕著な二次流れは観測されなかった . Re が 0.35 以上に増加する と PAAm 水溶液の場合では非定常流れか観測された . 特に, 湾曲が接続する蛇行流路の変曲点と光の近傍におい て, 強い変動と単一渦や双子渦の形を有する縦渦状の二次流れが生成された .

2. 粘弾性流体流れの管摩擦係数 $f$ は, $R e$ が小さい領域ではニュートン流体の定常層流流れの值と一致するが, 流 れが非定常となるRe の領域では $f$ はスクロース水溶液の場合と比較して顕著に増加した . 直線流路と蛇行流路の 場合では, $f$ は共にべき乗則流体の $f$ の值を上回るが, 両者を比較すると蛇行流路内流れの方が高い值を示した . 
したがって , 蛇行流路内ではより非定常性と渦の規模が強くなると考えられる．

3. 平均ヌッセルト数 $N u_{m}$ は, PAAm 水溶液はスクロース水溶液の場合と比較して顕著に増大し, 低いレイノルズ 数条件下でも高い伝熱促進効果が得られる . また , 同一ポンプ動力の条件下では, PAAm 水溶液の方が $N u_{m}$ が大 きく，ポンプ動力か増加するに従って弚の差か顕著となる .一方 , 直線流路内の粘弾性流体流れでは, 同一ポンプ 動力に対する $N u_{m}$ がスクロース水溶液の場合とほぼ等しくなることから，蛇行流路内の粘弾性流体流れの方がよ り高い総合性能が得られることが分かった .

謝 辞

本研究は,(独) 日本学術振興会科学研究費補助金 (若手研究 (B) : 22760149) による研究成果である.記して謝 意を表する .

文献

(1) Das, S.K., Choi, S.U.S., Yu, W., and Pradeep, T., "Nanofluids, Science and Technology", John Wiley \& Sons, (2007).

(2) Godson, L., Raja, B., Lal, D.M., and Wongwises, S., "Enhancement of Heat Transfer Using Nanofluids - An Overview", Renewable and Sustainable Energy Reviews, Vol. 14, (2010), pp. 629-641.

(3) Larson, R.G., Shaqfeh, E.S.G., and Muller, S.J., "A Purely Elastic Instability in Taylor-Couette Flow”, Journal of Fluid Mechanics, Vol. 218, (1990), pp. 573-800.

(4) Joo, Y.L., and Shaqfeh, E.S.G., "Observation of Purely Elastic Instabilities in the Taylor-Dean Flow of a Boger Fluid", Journal of Fluid Mechanics, Vol. 262, (1994), pp. 27-73.

(5) 横山俊雄, 富田幸雄 “ 希薄高分子溶液の曲がり管内流動に関する研究 (助走区間内流動)”, 日本機械学会論文集 B 編， Vol. 56, No. 8 (1990), pp.983-989 .

(6) Groisman, A., and Steinberg, V., "Efficient Mixing at Low Reynolds Numbers Using Polymer Additives", Nature, Vol. 410, (2001), pp. 905-908.

(7) 玉野真司, 伊藤 基之, 笹川哲, 横田和彦 “” 高分子水溶液の屈曲流路流れにおける二次流れのPIV 計測” , 日本機械学会 論文集 B 編，Vol. 75, No. 9 (2009), pp.2115-2121 .

(8) Teodor, B., Enrico, S., Groisman, A., and Steinberg, V., "Chaotic Flow and Efficient Mixing in a Micro Channel with a Polymer Solution", Physical Review E, Vol. 69, (2004), 066305.

(9) Li, F.-C., Kinoshita, H., Li, X.-B., Oishi, M., Fujii, T., and Oshima, M., "Creation of Very-low-Reynolds-number Chaotic Fluid Motions in Microchannels Using Viscoelastic Surfactant Solution”, Experimental Thermal and Fluid Science, Vol. 34, (2010), pp. 20-27.

(10) Giesekus, V.H., "Sekundärsträmungen in Viskoelastischen flässigkeiten bei Stationnärer und Periodischer Bewegung", Rheologica Acta, Vol. 4, (1965), pp. 85-101.

(11) Hartnett, J.P., and Kostic, M., "Heat Transfer to a Viscoelastic Fluid in Laminar Flow Through a Rectangular Channel", International Journal of Heat Mass Transfer, Vol. 28, No. 6 (1985), pp. 1147-1155.

(12) Xie, C., and Hartnett, J.P., "Influence of Rheology on Laminar Heat Transfer to Viscoelastic Fluids in a Rectangular Channel", Industrial and Engineering Chemistry Research, Vol. 31, (1992), pp.727-732.

(13) Naccache, M.F., and Mendes, P.R.S., "Heat Transfer to Non-Newtonian Fluids in Laminar Flow Through Rectangular Ducts", International Journal of Heat and Fluid Flow, Vol. 17, (1996), pp. 613-620.

(14) Norouzi, M., Kayhani, M.H., Nobari, M.R.H., and Demneh, M.K., "Convective Heat Transfer of Viscoelastic Flow in a Curved Duct”, World Academy of Science Engineering and Technology, Vol. 56, (2009), pp. 327-333.

(15) Shah, R.K., and London, A.L., Laminar Flow Forced Convection in Ducts, Advances in Heat Transfer, Supplement 1, Academic Press (1978). 
(16) Wiginton, C.L., and Dalton, C., "Incompressible Laminar Entrance Flow in a Circular Sector Duct", Journal of Applied Mechanics, Vol. 37, (1970), pp. 854-856.

(17) Gucker, F.T., and Ayers, F.D., "The Specific Heat of Aqueous Sucrose Solutions at $20^{\circ} \mathrm{C}$ and $25^{\circ} \mathrm{C}$ and the Apparent Molal Heat Capacity of Non-electrolytes", Journal of the American Chemical Society, Vol. 59, No. 3 (1937), pp. 447-452.

(18) Werner, M., Baars, A., Werner, F., Eder, C., and Delgado, A., “Thermal Conductivity of Aqueous Sugar Solutions under High Pressure", International Journal of Thermophysics, Vol. 28, (2007), pp. 1161-1180.

(19) Mirsa, B.N., and Varshni, Y.P., "Viscosity-Temperature Relation for Solution”, Journal of Chemical and Engineering Data, Vol. 6, (1961), pp. 194-196.

(20) ASME, Measurement Uncertainty, Performance Test Codes ANSI/ASME PTC 19.1-1985, (1986), The American Society of Mechanical Engineers, New York.

(21) Busse, W.F., "Mechanical Structures in Polymer Melts. II. Roles of Entanglements in Viscosity and Elastic Turbulence”, Journal of Polymer Science Part A-2, Vol. 5, (1967), pp. 1261-1281.

(22) Kays, W.N., and Crawford, M.E., Convective Heat and Mass Transfer, 2nd ed. (1980), pp. 275-287, McGraw-Hill.

(23) Kozicki, W., Chou, C. H., and Tiu, C., "Non-Newtonian Flow in Ducts of Arbitrary Cross-sectional Shape", Chemical Engineering Science, Vol. 21, (1966), pp. 665-679.

(24) Chandrupatla, A.R., and Sastri, V.M.K., "Laminar Forced Convection Heat Transfer of a Non-Newtonian Fluid in a Square Duct", International Journal of Heat Mass Transfer, Vol. 20, (1977), pp. 1315-1324. 